A Promising Problem 
THIS PAGE INTENTIONALLY LEFT BLANK 


\section{A Promising Problem}

\section{The New Chicana/o History}

EDITED BY CARLOS KEVIN BLANTON

University of Texas Press $\underset{\sim}{ }$ Austin 
Copyright (C) 2016 by the University of Texas Press

All rights reserved

Printed in the United States of America

First edition, 2016

Requests for permission to reproduce material from this work should be sent to:

Permissions

University of Texas Press

P.O. Box $78 \mathrm{r} 9$

Austin, TX 78713-7819

http://utpress.utexas.edu/index.php/rp-form

@ 0 The paper used in this book meets the minimum requirements of ANSI/NISO Z39.48-I992 (RI997) (Permanence of Paper).

\section{Library of Congress Cataloging-in-Publication Data}

A promising problem : the new Chicana/o history / edited by Carlos Kevin Blanton. - First edition.

pages $\mathrm{cm}$

Includes bibliographical references and index.

ISBN 978-I-4773-0896-7 (cloth : alk. paper) — ISBN 978-I-4773-0903-2 (pbk. : alk. paper) — ISBN 978-I-4773-IOI I-3 (library e-book) — ISBN 978-I-4773-IOI2-O (nonlibrary e-book)

I. Mexican Americans-Ethnic identity. 2. Mexican AmericansHistoriography. 3. Mexican Americans-Social conditions. 4. Mexican Americans-Study and teaching-History. I. Blanton, Carlos Kevin, I970- editor.

EI84.M5P76 2016

$973^{\prime} .046872-\mathrm{dc} 23$ 2015034520

doi: $10.7560 / 308967$ 